https://doi.org/10.18485/kud_kiaz.2019.ch43

\author{
Shalala Baghirova, $\mathrm{PhD}$ \\ Azerbaijan University of Languages \\ baghirova.shalala@mail.ru
}

\title{
ABOUT THE ACTIVITIES \\ OF THE CENTRAL HOUSE COMMITTEE
}

\begin{abstract}
SUMMARY
The article have researched the activities of the Central House Committee, which existed during the period of the Azerbaijan People's Republic and engaged in charity. The Committee was engaged in the registration of the people in need without distinction of religion, nationality, assistance to the poor, arrangement of foodstuff points, observance of cleanliness at home and in the yard, lighting of streets, fire protection and other problems.
\end{abstract}

Key words: assistance, charity, Centrodom, financial assistance, disease.

The First World War, which took place in 1914-1918, did not pass by the Azerbaijani territories within the Russian Empire. The war brought anarchy and arbitrariness to the country. Moreover, the massacres committed by Armenians against the Turkish-Muslim population in 1918 greatly damaged Azerbaijan, and the vast majority of the population were completely corrupted, deprived of their living space, wages, and was only in need of state care. The epidemic of infectious diseases has also spread to the country. The majority of refugees forced to leave their homelands in the provinces of Azerbaijan and the lack of normal conditions for 
their survival led to an increase in infectious diseases [2, $\mathrm{p}$. 340]. Azerbaijan Democratic Republic, which proclaimed its independence on May 28, 1918, in its turn, had to prepare an action plan to accelerate the development of assistance to the population in all areas.

Central House Committee (Centrodom) was one of the largest charitable societies operating during the period of existence of Azerbaijan Democratic Republic. The Committee was established in September 1918. House committees existed before it started. The committee, which was far from politics, was particularly important in its struggle against poverty and misery. The Central House Committee was engaged in the registration of the population, assistance to the poor, cleanliness at home and in the yards, lighting of the streets, fire protection and other problems without distinction of religion, national affiliation. A.Leontovic was elected as the Chairman of the Committee. It should be noted that during the genocide committed by the Dashnak-Bolshevik forces in Baku in March 1918, A.Levontovic's wife and three-year-old son were killed. He was shot in April 1920 when the Azerbaijan Democratic Republic was overthrown.

City Field Committees of the Central House Committee also operated. In connection with the settlement of refugees in the city, these institutions have close contact with sanitary doctors in the fight against infectious diseases, informing them in suspicion. For example, the $7^{\text {th }}, 8^{\text {th }}, 9^{\text {th }}$ committees prevented the spread of parasites among the population. In this connection, the city municipality organized disinfection cameras by making agreement with the Central House Committee. People infected with louse handed over their clothes and bedding to these cameras and got them back after they were cleaned [5].

Those who need help applied to the Central Committee for Assistance, the Committee conducted investigations and sent a letter to the Minister of Portection on the basis of the information received. We would like to highlight some of 
these letters: According to the $8^{\text {th }}$ Committee's Investigation, Maria Antonovna Sushinskaya's husband is missing, she is ill, in desperate state and has no help. Therefore, her request for help may be considered as reasonable by the Centrodom's opinion. The Central House Committee reports that Khanim Najaf's need for help has been investigated by the $3^{\text {rd }}$ Field Committee, it is approved that the woman is in bad condition. According to the $3^{\text {rd }}$ field committee's investigation, Bikakhaman Mammadrza, with her 5 minors, is in a very poor state of living, "Information on living conditions of Levinova Maria, Dobanova Aksinya, Stepanians Tatevos, Belousova Yevdokiya's has been received by the $6^{\text {th }}$ Field Committee, and the Committee decided that they were extremely poor and they had not any fund for existence. According to the field committee, those who have been mentioned are in need of financial assistance".

The Central House Committee held elections in the Muslim-majority areas and raised the issue of their activity. It should be noted that the Muslims living areas of the city was in a pitiable situation. Domestic commissions were organized after the March genocide. The Turkish-Muslim population, which was unable to escape the horrors of this period, was overwhelmed by resentment, fears, frustration and misery. For this reason, the Turkish-Muslims were unable to think about it while the urban population was mobilized in the fight against hunger and anarchy, and there was no organizational work among them. In the activities of home committees, this part of the city was almost non-existent. Therefore, the terrible famine that took place during the summer months was particularly cruel to this part of the city and gradually deteriorated. These days were summarized as follows in pages of the press: "Death is about victory over weakness of will and consciousness. It is very shameful, awful, terrible, and hard for humanity: hunger strikers, wolves, poor people - people die in the streets and in front of the people of the big city. The Turkish-Muslim population must draw conclusions from 
these hard lessons and their involvement in the functioning of this new society is inevitable"...

At this time, the Central House Committee created conditions for the Turkish-Muslim population. The Muslims had the right to be represented by their representatives in the committee. In general, the Central House Committee has taken over the task of ensuring the safety of the population, taking all its home committees under their control.

A.Leontovic had a great interest in the work of the committee among all the layers of the population. Interestingly, until he left his job, he was called as Centrodom among the people ... The deputies of the Centrodom were M. Shor, Aliheydar Allahverdiyev and G.Malikdadayev. Departments of the committees were managed by $\mathrm{G}$. Lopatinsky, B.Klementyev, M.Zelenkevich, G.Bron, A. Taghiyev, U.Goychayev [9, p. 91]. From January 16, 1920, the chairmanship of the committee was assigned to Alibey Gulubeyov [6]. In general, the Central House Committee had been closely involved in providing assistance to the entire population irrespective of their religion, nationality. According to statistical data, the total population of Azerbaijan was 2861862 people. They were:

- 1952250 Muslims - 68,2\%;

- 622006 Armenians- 21,4\%;

- 14794 Georgians - 0,6\%;

- 2149930 Russians - 7,5\%;

- 57882 other peoples $-2,3 \%$ [8].

The Central House Committee consisted of four groups: nutrition points, food department, law department, sanitation department.

Nutrition points were free of charge for those in need. The person responsible for this work was selected by G.Bron. All the food points were involved in the department's work. Feeding points started operating on September 27 [9, p.91]. About 3,000 people were given free meals each day during the first week. Meals were available for those who were registered 
in the Central House Committee and who had a certificate of poverty. Free meals were given to those with special marks on the ticket.

It should be noted that the Muslim population refused to eat at food of these points, so it was decided to open a special food distribution point. These stations serve only Muslims, provided them with flour, rice, and beans.

Food department was organized in January 1919. The main task of the department was to provide poor people with cheap and high quality products. The department had trade, supply and distribution divisions. Since January 3, bakeries have started to operate. There were 10 shops in the committee to organize the sale of bread. In Muslim neighborhoods, special shops were organized to sell tandoor bread. Generally, Centrodom did its best to provide the population with cheap, but high-quality food products [4].

The legal department was organized to provide cheap legal assistance to the population. The department was mainly engaged in housing affairs.

The Health Department also fought infectious diseases in residential areas in the city. Cleaning work was being carried out in this city. The medical staff of the department provided free medical aid to the population. The bath for the poor people was also organized.

As it was noted, massive infectious diseases were spread in and around Baku. City hospitals operated under severe conditions. The overwhelming majority of patients, the shortage of medical staff, the lack of discipline - all this caused difficulties. The anti-sanitary and the infectious diseases that existed in the city almost killed hundreds of people every day. These conditions urgently required the implementation of an action plan to improve the health of the city. According to the Central House Committee, field committees also exercised control over the compliance with the requirements of the health department. Those who did not observe the rules were deprived of the Committee's services by the Central Committee. 
One of the measures taken by the Central Committee of Sanitary Commissions on the widespread epidemic was to promote the activities of those responsible for cleaning. These people had to sweep yards twice a day, at 6-7 o'clock in the morning and 4-5 o'clock in the evening, and burned the garbage immediately. The remains of burnt garbage should be filled in recycle bins and they should be closed.

Since its establishment, the Central House Committee has been interested in the fate of children who lost their parents during the events of March and September. In connection with this issue, in September 1918, the Committee established a Bureau of Child Assistance under the chairmanship of Dr. Y.Y.Gindes on the proposal of the Ministries of Public Health and Social Welfare [7, 221]. His deputy was Liza Mukhtarova.

The Bureau was organized in March 1918 to help the children of the streets who were left homeless as a result of the genocide committed by the Bolshevik-Dashnak forces against the Azerbaijani people. There were almost no children in Baku who did not suffer from these catastrophes. These children were in need of special care. Dr. Gindes undertook all of this.

At the disposal of the Child Assistance Bureau, there were five shelters in the village where at least a thousand children could be accommodated. One of the shelters was a nursery home for orphans with the help of Ms. Liza Mukhtarova in December. This shelter was opened on the basis of the "Nursing Home", which operated from 1895 to 1917. Then the chairman was Dr. Gindes, and the financier was Haji Zeynalabdin Taghiyev. H.Z.Taghiyev was later elected as honorary member of society.

The People's Health and Defense Ministries closely cooperated with the Central House Committee. The mentioned ministries closely participated in the organization of foodstuffs for the poorest part of the city in Shamakhinka, Icherisheher, Garashahar, Bayil, Molokan and other places. It should be noted that the Chairman of the Cabinet of Ministers, Fatali 
Khan Khoyski, was very interested in the work of the society and helped to solve the problems. In spite of the ongoing social and political problems, for the sake of the welfare of the society, supporting the activities of all charitable organizations in Centrodom's example was one of the important tasks of the state. Only in December 1919, the Cabinet of Ministers allocated free loans to the municipality of Baku in the amount of 2200,000, and for Ganja Municipality - 450000 rubles for the struggle against spotted fever. In general, the Central House Committee, following carefully obeying all these tasks, has managed to prevent thousands of people from starvation and the destruction of city-wide epidemics. In a controversial period, the Central House Committee, which carried out a complicated and important task as charity, could not have been perfect. However, despite this, the charity community has peculiar traces in the history of Azerbaijan.

\section{Odəbiyyat:}

Azərbaycan Xalq Cumhuriyyəti Ensiklopediyası. İki cilddə, I cild, Bak1-2004.

Azərbaycan Xalq Cumhuriyyəti Ensiklopediyası. İki cilddə, II cild, Bak1-2004.

Azərbaycan qəzeti. 23 oktyabr, 1918-ci il, №3.

Azərbaycan qəzeti. 27 noyabr, 1918-ci i1, №46.

Azərbaycan qəzeti. 1 yanvar, 1919-cu il, №1.

Azərbaycan qəzeti. 18 yanvar, 1920-ci il, №12.

Алиева Лятифа. Женщины в общественно-политической жизни Азербайджана (1900-1920 гг.). Баку, 2013.

Адрес-календарь. 1920.

Гусейнова Лала. Деятельность неправительственных общественных организаций в период АДР (1918-1920). 


\section{PЕЗЮМЕ}

В данной статье исследуется деятельность Центрального Домового Комитета занимающийся благотворительностью в период Азербайджанской Демократической Республики. Комитет занимался регистрацией бедного населения не зависимо от национального происхождения, помощью нищим, организацией питательных пунктов, наблюдением чистотой в домах и во дворах, освещением улиц, противопожарной защитой и др. делами.

Ключевые слова: нужда, болезнь, Центральной Домовой Комитет, помощь, благотворительность. 